\title{
A Julio Rodríguez Puértolas, maestro amado, y amigo entrañable de Verba Hispanica
}

\section{In memoriam}

A finales de septiembre de 2017, murió Julio Rodríguez Puértolas, mi maestro amado en la Universidad Autónoma de Madrid, allá por los años del final de la dictadura franquista y del comienzo de la Transición; y, luego, amigo, y referente entrañable para mí, hasta el final de sus días... Pero también, desde el principio mismo de nuestra andadura como anuario de filología hispánica, amigo, impulsor y colaborador de nuestra Verba Hispanica, pues él fue una de las primeras personas a las que recurrimos, cuando la fundamos... Y, por su mediación, no solo nos llegaron muchos artículos y conocimos a muchos de nuestros colaboradores, sino que él mismo personalmente contribuyó con su presencia en el simposio celebrado en Ljubljana, con motivo del centenario de la Primera parte de Don Quijote, en 2005, y con su participación en la revista, a estrechar unos lazos de amistad que han durado también hasta el final. ¡Cuántas veces, en estos años, hemos recordado los días pasados en Ljubljana y la cariñosa acogida de todo el Departamento, encabezado aún por el profesor Mitja Skubic! ...

Por eso, y por su significado dentro de la crítica literaria social y materialista universitaria en español, como discípulo de don Américo Castro, primero, o como profesor en Estados Unidos, durante los años sesenta, y como catedrático de literatura, finalmente, en la Universidad Autónoma de Madrid, durante los años setenta, ochenta y noventa, en donde terminó coordinando los simposios anuales sobre «La Cultura durante la II República», que tienen lugar cada primavera en su seno... $\mathrm{O}$, antes, como coautor, junto con Iris $\mathrm{Za}-$ vala y Blanco Aguinaga, de la mítica Historia Social de la Literatura Española (en castellano), que sacudió los vetustos cimientos positivistas e idealistas de la crítica literaria universitaria española, durante la Transición, y que tanto nos influyó a los jóvenes estudiantes de filología de entonces, y de generaciones posteriores... Por todo ello, Verba Hispanica le dedicó un número especial 
de homenaje a su obra y a su figura, en el año 2007. Y, por eso, ahora le dedicamos estas sentidas palabras de memoria y reconocimiento a esa misma obra y a esa misma figura señera, pero, sobre todo, al amigo cordial de Verba Hispanica y al maestro de tantos de nosotros.

Por su mediación, los textos fundacionales de nuestra literatura castellana, especialmente los grandes textos del siglo XIV, y principalmente el Libro de Buen Amor, adquirieron para nosotros un nuevo y vivo sentido... Cómo olvidar tampoco sus estimulantes lecturas del Romancero tradicional, de $\mathrm{La}$ Celestina o del episodio de la bella Marcela, en Don Quijote... O el completo desentrañamiento del Galdós más lúcido y cervantino, o del Clarín más cortante... Todos los lectores atentos y los estudiantes de filología inquietos y curiosos que se acerquen a su obra y a su legado no se sentirán defraudados y su lectura les abrirá un nuevo modo de entender la literatura como respuesta material y política, en sentido estricto, al mundo del que nace y surge; no como por magia desligada, sino como diálogo esclarecedor y problemático. Descansa en paz, maestro y amigo. No te olvidamos.

Matías Escalera Cordero 